\title{
Increased Single-Nucleotide Discrimination of PCR by Primer Probes Bearing Hydrophobic 4'C Modifications
}

\author{
Michael Strerath, Jens Gaster, Daniel Summerer, and Andreas Marx*[a]
}

We report on significantly increased selectivity of real-time $P C R$ through employment of primer probes that bear hydrophobic $4^{\prime} \mathrm{C}$ modifications at the $3^{\prime}$-terminal nucleotide. The primer probes were designed to bind the target sequences in such a way that the 3'terminal nucleotide defines whether a matched or a single mismatched basepair is present depending on the respective target sequence. Several commercially available thermostable DNA polymerases belonging to different DNA polymerase families were tested for their efficacy in discriminating between PCR amplification of matched substrates and duplexes that contain a single mismatch. It turned out that, depending on the $4^{\prime} \mathrm{C}$ modification and the employed DNA polymerase, significantly increased differentiation between single matches and mismatches could be observed with real-time PCR. The degrees of the observed effects varied with the employed $4^{\prime} \mathrm{C}$ modification and the sequence context studied. The system is robust enough to work faithfully under several buffer conditions. Our approach should be useful for the direct diagnosis of single nucleotide variations within genes, like single nucleotide polymorphisms or mutations, by PCR without the need for further time- and cost-intensive post-PCR analysis.

\section{Introduction}

Since the sequence of the human genome was deciphered, the elucidation of genomic dissimilarities like single nucleotide polymorphisms (SNPs) between different individuals has been the main focus of many research efforts. ${ }^{[1-3]}$ These nucleotide variations within the genome are often linked to variable effects of drugs on different patients or predisposition for various diseases. ${ }^{[2-4]}$ Endeavors in this direction led to the advent of pharmacogenetics and pharmacogenomics..$^{[1-6]}$ In the future, the exact knowledge of medicinally relevant nucleotide variations might enable the adaptation of any therapy to the respective genetic make-up of the individual and should allow the prediction of interindividual drug efficacy and/or toxicity. Thus, treatment with drugs that are ineffective or cause severe side effects could be abolished. ${ }^{[1-6]}$ Obviously, methods that allow time- and cost-efficient verification of nucleotide variations will lead to further advances along these lines.

To date many methods for the detection of nucleotide variations in genes have been described. All methods have advantages and disadvantages, and thus no methodology has prevailed so far. ${ }^{[7-15]}$ Most known methods share the common feature that they are applied after amplification of the target genome sequence by the polymerase chain reaction (PCR). ${ }^{[7-15]}$ Thus, after isolation of the genetic material from an individual, the sequence of interest has to be amplified by PCR prior to the analytical step determining the nucleotide variation. Obviously, analysis of the absence or presence of a nucleotide variation in a specific single position within the entire genome directly by PCR would be superior to any post-PCR nucleotide detection method. Nevertheless, methods for the direct detection of nucleotide variations by PCR are rare. ${ }^{[13-15]}$ Allele-specific amplification has been described to report nucleotide variations through either the presence or absence of a DNA product obtained through PCR amplification. ${ }^{\text {16-19] }}$ The principle of this approach is based on the formation of matched or mismatched primer-template complexes through allele-specific primer probes. PCR amplification by a DNA polymerase from matched 3'-primer termini proceeds, while a mismatch should obviate amplification. Nevertheless, there have been numerous reports indicating low selectivity with this approach that necessitates further tedious time- and cost-intensive sequence and assay designs and buffer optimizations. ${ }^{[20-23]}$ Any means to increase the selectivity and robustness of allele-specific PCR amplification should have a significant impact on the reliability and robustness of direct nucleotide variation analysis by PCR.

\footnotetext{
[a] Dipl.-Chem. M. Strerath, Dipl.-Chem. J. Gaster, Dipl.-Chem. D. Summerer Priv. Doz. Dr. A. Marx

Kekulé-Institut für Organische Chemie und Biochemie Universität Bonn

Gerhard-Domagk-Strasse 1,

53121 Bonn (Germany)

Fax: $(+49)$ 228-735388

E-mail:a.marx@uni-bonn.de
} 
Recently, we have found that the selectivity of nucleotide insertion by a DNA polymerase can be increased through the employment of $4^{\prime} C$-alkylated nucleotides. ${ }^{[24-28]}$ Furthermore, first preliminary model studies indicate that primer probes bearing nonpolar $4^{\prime} \mathrm{C}$ modification have significant effects on single mismatch discrimination in allele-specific PCR amplification. ${ }^{[29,30]}$ In comparison to unmodified primer probes, we found that significantly higher amplification selectivity is observed with employment of $4^{\prime} \mathrm{C}$-modified primer probes and a commercially available $3^{\prime}-5^{\prime}$-exonuclease-deficient variant of Vent DNA polymerase (Vent (exo-)).

Here we present an in-depth study of various new primer probes bearing nonpolar $4^{\prime} \mathrm{C}$ modifications that have not been investigated in allele-specific PCR before. Additionally, the effects of the modifications on several thermostable DNA polymerases were compared. Here we employed real-time PCR by using fluorescent SybrGreen I detection as a rapid and convenient tool to follow and analyze the degree of allele discrimination. ${ }^{[31,32]}$ We found that some $4^{\prime} \mathrm{C}$ modifications are able to significantly increase amplification selectivity. Interestingly, the observed effects depend on the nature of the modification and the employed DNA polymerase. Most remarkably, single nucleotide discrimination selectivity was robust under various buffer conditions and within several medicinally relevant sequence contexts that were examined.

\section{Results}

In order to investigate the impact of $4^{\prime} \mathrm{C}$ modifications on the selectivity of PCR amplification promoted by several DNA polymerases, we synthesized primer probes bearing various $4^{\prime} \mathrm{C}$-modified thymidines at the $3^{\prime}$ terminus (Scheme 1). The new analogues were synthesized by employing only minor modifications of published procedures. ${ }^{[33]}$

In the first set of experiments, we investigated several commercially available and thermostable DNA polymerases with respect to the effects of the modified $4^{\prime} \mathrm{C}$-modified primer probes. These experiments were conducted in the sequence context of human acid ceramidase comprising the recently discovered transition mutation $A 107 G$, which is involved in the onset of Farber disease. ${ }^{[34]}$ Two reactions were conducted in each particular set of experiments. One PCR was conducted with the wild-type template
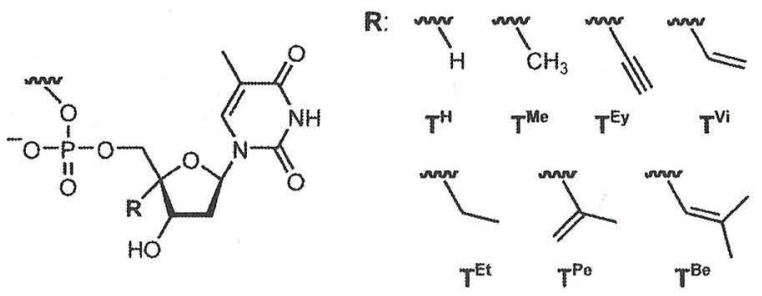

Scheme 1. $4^{\prime} \mathrm{C}$-Modified thymidine residues $T^{R}$ incorporated into primer probes. respectively. bearing a dA residue opposite the $3^{\prime}$-terminal thymidine in the primer probe. In the other experiment the same primer probe was used along with a template strand with the same sequence apart from the $d A \rightarrow d G$ mutation. Both set-ups contained the same reverse primer. In this study we analyzed the reaction by employing real-time detection of SybrGreen I fluorescence upon binding to double-stranded DNA by using appropriate thermocycler equipment. We compared the efficacy of the performance of the primer probes with Vent(exo-), Exo- Pfu, and Taq DNA polymerases. We used DNA polymerases deficient in $3^{\prime}-5^{\prime}$ exonuclease activity since this intrinsic repair function is known to excise noncanonical nucleotides at primer termini before resuming DNA synthesis. ${ }^{[35,36]}$ This enzyme activity would cause the primer probes to lose their discriminating features. When we employed Vent(exo - ) DNA polymerase in the supplied reaction buffer and unmodified $\mathrm{T}^{\mathrm{H}}$ primer probe in combination with the wild-type template a rise in the fluorescence was detected with increasing cycle number. Nevertheless, almost superimposable curves were obtained when the mutant template was employed (Figure 1).

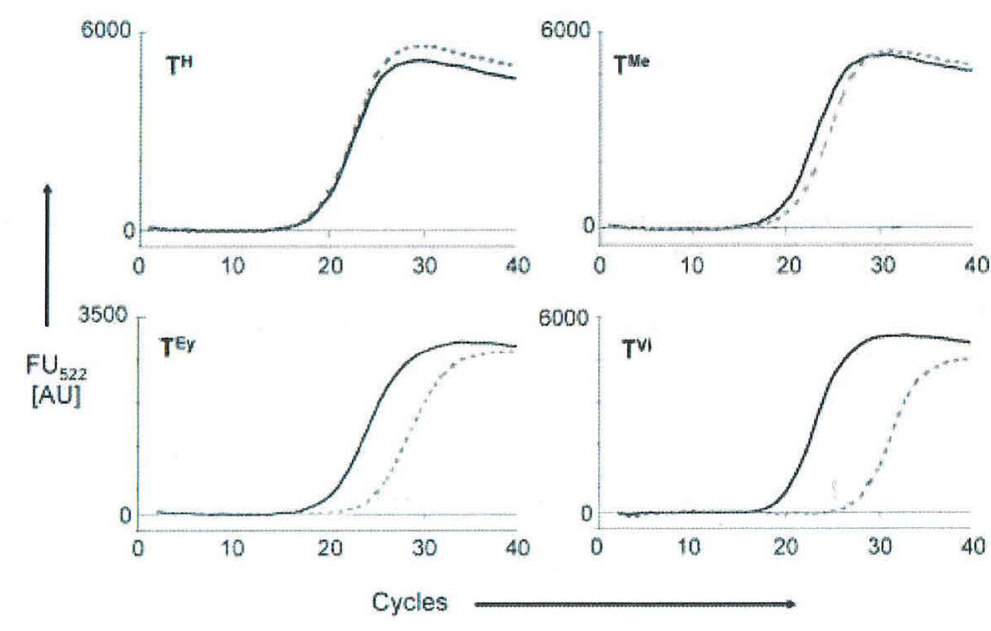

Figure 1. Results of real-time $P C R$ experiments obtained with primer probes bearing thymidine residues $T^{R}\left(R=4^{\prime} C\right.$ modifications as indicated in Scheme 1) at the $3^{\prime}$ end. $P C R$ amplification in the presence of matched target template FarA (-) or mismatched template FarG (--.-),

These results indicate the inability of this DNA polymerase to discriminate between the amplification of a canonical primertemplate complex and a primer-template complex that contains single mismatches, a fact in accordance with published reports. ${ }^{[20-23]}$ When the bulk at the $4^{\prime} \mathrm{C}$ position was increased and the $T^{\text {Me }}$ primer probe was employed, only a marginal shift of both curves was observed, a result indicating that the single nucleotide discrimination is still low. However, further increase of the bulk by using the $4^{\prime} \mathrm{C}$-ethynylated $T^{\mathrm{E} y}$ probe resulted in a significant shift of both curves. As depicted in Figure 1, the difference between the threshold crossing points $\left(\Delta C_{t}\right)$ of both curves is about six cycles. This difference between wild-type (matched) and mutant (mismatched) amplification by PCR 
indicates that the $4^{\prime} \mathrm{C}$-modified probe is able to increase the selectivity in comparison to the unmodified system. The $\Delta C_{t}$ value between the matched and mismatched systems increased further when $\mathrm{T}^{\mathrm{Vi}}$ or $\mathrm{T}^{\mathrm{Er}}$ were used in the primer probes (Figure 1, Table 1). Increasing the bulk at the $4^{\prime} \mathrm{C}$ position further through use of $T^{\mathrm{Pe}}$ or $\mathrm{T}^{\mathrm{Be}}$ resulted in the failure of amplification of the desired product.

\begin{tabular}{|c|c|c|c|}
\hline$T^{R}$ & Taq & $\begin{array}{l}\Delta C_{\mathrm{t}} \text { values with } \\
\text { Pfu exo }\end{array}$ & Vent (exo-) \\
\hline $\mathrm{T}^{\mathrm{H}}$ & 1 & 1 & 0 \\
\hline $\mathrm{T}^{\mathrm{Me}}$ & n.a. ${ }^{[a]}$ & 5 & 0.5 \\
\hline$T^{\text {Ey }}$ & n.a. ${ }^{[a]}$ & n.a. ${ }^{[a]}$ & 5.5 \\
\hline $\mathrm{T}^{\mathrm{Vi}}$ & n.a. ${ }^{[a]}$ & n.a. ${ }^{[a]}$ & 8 \\
\hline$T^{E t}$ & n.i. ${ }^{[b]}$ & n.a. ${ }^{[a]}$ & 8.5 \\
\hline$T^{\mathrm{Pe}}$ & n.j..$^{[b]}$ & n.a. ${ }^{[\mathrm{a}]}$ & n.a. ${ }^{[a]}$ \\
\hline $\mathrm{T}^{\mathrm{Be}}$ & n.a. ${ }^{[a]}$ & $\mathrm{n} \cdot \mathrm{a}^{[\mathrm{a}]}$ & n.a. ${ }^{[a]}$ \\
\hline
\end{tabular}

[a] n.a.: no amplification after 40 cycles of PCR. [b] n.i.: not investigated.

Next we investigated whether the observed effects are exclusively linked to Vent(exo-) DNA polymerase or whether other thermostable DNA polymerases exhibit similar features. Thus, Taq and Exo- Pfu DNA polymerases were studied in the same context by using the same thermocycling program and the buffer supplied by the respective manufacturers. In results consistent with the effects described above, Taq DNA polymerase was not capable of discriminating between the wild-type and mutant templates under standard conditions (that is, usage of supplied buffer) when the unmodified primer was employed. Interestingly, no amplification product was observed when Taq DNA polymerase was used with any of the modified primer probes depicted in Scheme 1. In contrast, Exo- Pfu DNA polymerase was capable of amplifying $T^{\text {Me }}$ primer probes and exhibited a $\Delta C_{t}$ value of five cycles between the wild-type and mutant templates in favor of amplification of the canonical wildtype sequence. Under the same conditions Exo- Pfu DNA polymerase was incapable of distinguishing between unmodified-primer-template complexes in the matched and mismatched cases. Interestingly, PCR amplification failed when bulkier $4^{\prime} \mathrm{C}$ modifications were employed. All the investigated DNA polymerases failed to achieve any significant single nucleotide discrimination selectivity in allele-specific PCR when unmodified primer probes were employed. Although the ability to amplify $4^{\prime} \mathrm{C}$-modified primer probes varied significantly among the enzymes tested, in cases where a DNA polymerase was competent to amplify $4^{\prime} \mathrm{C}$-modified primer probes, amplification was accompanied by an increase in the discrimination of single nucleotide mismatches.

Based on the results described above Vent(exo-) DNA polymerase appeared to be the most promising for further investigations. Next, we investigated whether discrimination was dependent on the nature of the mismatch in the same sequence context. Thus, in separate experiments the nucleobase in the template strand was varied, and we investigated the amplification with $T^{R}$ primers $(\mathrm{R}=\mathrm{H}$ or $\mathrm{Vi})$ and templates with $\mathrm{dC}$ and $\mathrm{T}$ mutations, respectively. As shown in Figure 2 employment of the $4^{\prime} \mathrm{C}$-vinylated $\mathrm{T}^{\mathrm{Vi}}$ primer probe led in all cases to discrimination comparable to that observed above. Under identical conditions unmodified primer probes failed to induce significant discrimination in these cases.

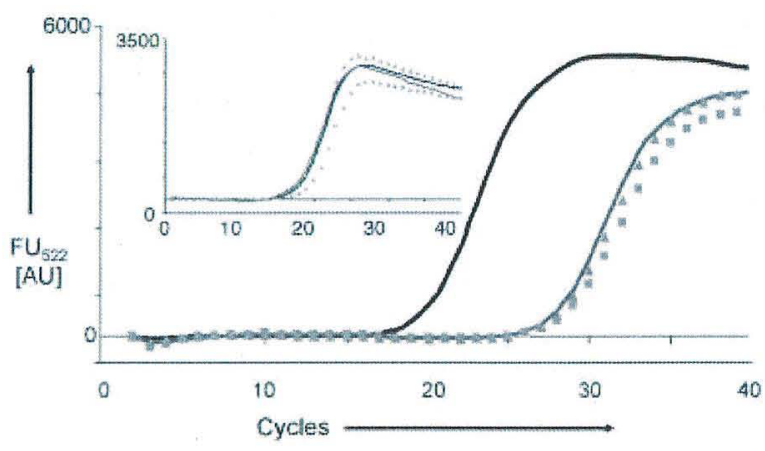

Figure 2. Results of real-time $P C R$ experiments obtained with primer probes bearing thymidine residues $T^{R}$ where $R=H$ (inset) or Vi (see Scheme 1) at the $3^{\prime}$ end. $P C R$ amplification in the presence of target template FarA (black line) or FarG (gray line), FarC (squares), and FarT (triangles), respectively.

Subsequently we investigated whether the established system composed of Vent(exo-) DNA polymerase and the $T^{\mathrm{Vi}_{\mathrm{i}}}$ primer probe is capable of genotyping in the context of the sequence of human acid ceramidase and the mutation A107G (which leads to the Farber disease) by employing human genomic DNA. The human genomic DNA employed has a deoxyadenosine at the locus of interest. We employed $T^{V_{i}}$ and $\mathrm{dC}^{V_{\mathrm{i}}}$ primer probes, respectively, and designed a reverse primer strand such that a 78-mer amplicon was obtained. As depicted in Figure $3, a \Delta C_{t}$ value of seven cycles was obtained between the matched $\mathrm{T}^{\mathrm{Vi}}$ probe and the mismatched $\mathrm{dC}^{\mathrm{Vi}}$ probe.

Thus, we could show for this example that the set-up used enabled us to draw conclusions concerning the sequence of a single nucleotide within the entire human genome directly through PCR. It should be mentioned that the reaction buffer supplied by the manufacturer was used in all experiments and no attempts were made to optimize the reaction conditions. The same applies to the thermocycling program, which is known to have a impact on the outcome of a PCR. ${ }^{[20]}$ Exactly the same program was applied in the experiments described above and those employing human genomic DNA. These results indicate that our system is robust enough to yield meaningful results.

Next, we investigated whether the ability of our system to discriminate significantly between single nucleotide differences could be applied to different sequence contexts. Thus, we investigated three additional recently discovered single nucleotide variations that are of considerable medicinal interest. The factor V Leiden G1691A mutation is believed to be responsible for a predisposition to thrombosis; ${ }^{[37,38]}$ the BRAF somatic T1796A mutation is present in a high percentage of malignant melanomas and, with lower frequency, in a wide range of human 

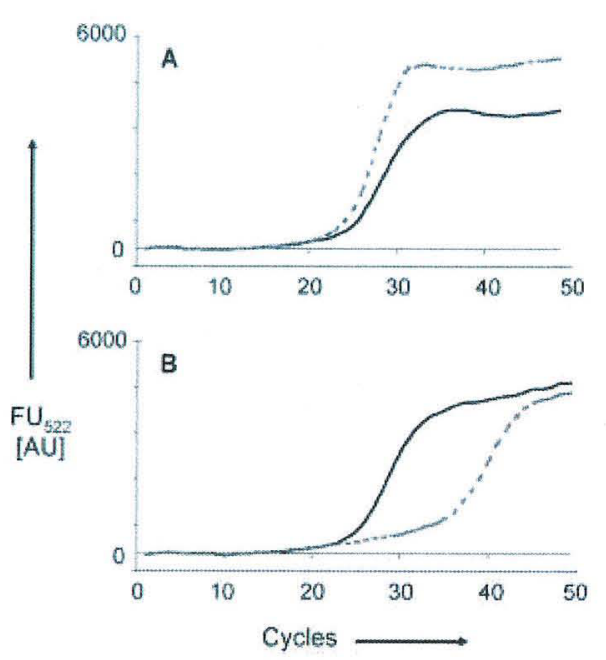

Figure 3. Real-time $P C R$ experiments with human genomic DNA in the sequence context of human acid ceramidase and the mutation A107G, which results in the onset of the Farber disease. The human genomic DNA sample employed is wildtype A107. A) Results obtained with primer probes bearing 3'-terminal $T^{H}$ (-) or $d C^{H}(-\cdots)$ residues. B) Results obtained with primer probes bearing $3^{\prime}$-terminal $T^{v i}$ $(\longrightarrow)$ or $d C^{v_{i}}(-\ldots)$ residues.

cancers, ${ }^{[39]}$ mutation $\mathrm{G} 735 \mathrm{~A}$ in the human dihydropyrimidine dehydrogenase (DPyD) leads to reduced activity of this enzyme, and treatment with the anticancer drug 5 -fluorouracil (5-FU) results in fatal haematopoietic, neurological, and gastrointestinal toxicities since the mutated enzyme is inefficient in inactivating 5-FU. ${ }^{[4,40]}$ The primer strands for these experiments were designed by standard computational means to result in comparable melting temperatures for both the nucleotidevariation-determining probe and the reverse primer strand. ${ }^{[4]}$ The results obtained are depicted in Table 3 . It is apparent that under identical PCR conditions to those applied before significantly increased single nucleotide PCR discrimination was still obtained through employment of $4^{\prime} \mathrm{C}$-modified probes in comparison to that with the unmodified counterparts (Table 2).

Interestingly, while the amplification of $T^{\text {Et }}$ primer probes failed in some of the investigated cases these probes gave superior results in the sequence context of DPyD. Nevertheless, the apparent degree of discrimination expressed in $\Delta C_{t}$ values varied among the sequence contexts investigated, and there was room for further improvement along this line.

\begin{tabular}{|c|c|c|c|c|}
\hline \multirow[t]{2}{*}{$T^{R}$} & \multicolumn{4}{|c|}{$\Delta C_{t}$ values for } \\
\hline & FarA vs. FarG & LeiA vs. LeiG & BrafA vs. Braft & DPyDA vs. DPyDG \\
\hline$T^{H}$ & 0 & 1 & 1.5 & 1.5 \\
\hline$T^{V i}$ & 8 & 10 & 4.5 & 4.5 \\
\hline$T^{\mathrm{Et}}$ & 8.5 & n.a. ${ }^{[a]}$ & n.a. ${ }^{[a]}$ & 7 \\
\hline
\end{tabular}

In contrast to our approach, former reports indicate that single nucleotide discrimination might be detected through tedious buffer optimization for every sequence of interest. ${ }^{[20]}$ These observations indicate that the ability of a DNA polymerase to differentiate faithfully between single nucleotide variations is strongly linked to buffer composition. In order to elucidate the response of our system to various buffer compositions we investigated the ability of Vent(exo-) DNA polymerase to differentiate between the $A 107 \mathrm{G}$ mutation in the sequence context of human acid ceramidase (that is, the same sequences employed in the experiments depicted in Table 1) when the $T^{\mathrm{Vi}}$ primer probe was employed in several reaction buffers. The buffers were varied in such a way that a single component was altered with respect to the original buffer. The results obtained are depicted in Table 3 and indicate some crucial parameters.

\begin{tabular}{|c|c|c|c|c|}
\hline $\mathrm{pH}$ & $\mathrm{KCl}[\mathrm{mm}]$ & $(\mathrm{NH})_{2} \mathrm{SO}_{4}[\mathrm{~mm}]$ & $\mathrm{MgSO}_{4}[\mathrm{~mm}]$ & $\Delta C_{t}$ \\
\hline 8.8 & 10 & 10 & 2 & 8 \\
\hline 6.8 & 10 & 10 & 2 & n.a. ${ }^{[a]}$ \\
\hline 8.3 & 10 & 10 & 2 & 6 \\
\hline 8.8 & 5 & 10 & 2 & 6 \\
\hline 8.8 & 20 & 10 & 2 & 2 \\
\hline 8.8 & 10 & 5 & 2 & 2 \\
\hline 8.8 & 10 & 20 & 2 & 5 \\
\hline 8.8 & 10 & 10 & 1 & 6 \\
\hline 8.8 & 10 & 10 & 2.5 & 7 \\
\hline 8.8 & 10 & 10 & 3.5 & 5 \\
\hline
\end{tabular}

Potassium chloride, ammonium sulfate, and a $\mathrm{pH}$ value lower than 8.3 seem to have the most significant impact on single nucleotide discrimination. Nevertheless, over a wide range of buffer compositions the system comprising Vent(exo-) DNA polymerase and $4^{\prime} \mathrm{C}$-modified $\mathrm{T}^{\mathrm{Vi}}$ primer probe appears to be robust enough to detect single nucleotide variations reliably.

To obtain first insights into the mechanisms that govern the observed effects we conducted thermal denaturating studies. $^{[33,42]}$ It is well known that terminal mismatches in small DNA duplexes have negligible effects on the thermal duplex stability. ${ }^{[43]}$ Nevertheless, so far it is not known if the same holds true for $4^{\prime} \mathrm{C}$-modified residues. In order to elucidate whether $3^{\prime}$ terminal $4^{\prime} \mathrm{C}$ modifications in primer-template complexes trigger increased differences between stabilities of canonical over noncanonical duplexes, we performed thermal denaturing studies and measured the melting temperature $\left(T_{m}\right)$ values of all mismatches opposite the respective $T^{R}$ primer probes. The results obtained are summarized in Table 4 and indicate no significant impact of $4^{\prime} \mathrm{C}$-modified residues on the duplex melting behavior. 


\begin{tabular}{|c|c|c|c|}
\hline Template modification & $\mathrm{T}^{\mathrm{H}}$ & $\begin{array}{c}T_{\mathrm{m}}\left[{ }^{\circ} \mathrm{C}\right] \text { with } \\
\mathrm{T}^{\mathrm{Vi}}\end{array}$ & $\mathrm{T}^{\mathrm{Et}}$ \\
\hline $\mathrm{dA}$ (wild-type) & 61.8 & 61.2 & 60.9 \\
\hline dG & 60.5 & 60.4 & 60.6 \\
\hline $\mathrm{dC}$ & 61.0 & 60.7 & 61.2 \\
\hline T & 61.5 & 61.4 & 61.4 \\
\hline
\end{tabular}

Thus, the marked selectivity of single nucleotide discrimination promoted by Vent(exo - ) DNA polymerase in the presence of $4^{\prime} \mathrm{C}$-modified probes is unlikely to be derived from differential duplex stabilities of $4^{\prime} \mathrm{C}$-modified versus unmodified duplexes.

\section{Discussion}

This study describes the effects of hydrophobic $4^{\prime} \mathrm{C}$ modifications in primer probes on single nucleotide discrimination by PCR amplification. We found that, in contrast to the use of unmodified primer probes, employment of $4^{\prime} \mathrm{C}$-modified primer probes enables differentiation between matched and mismatched complexes through different amplification behavior, as analyzed by real-time PCR. Thus, the sequence at a single nucleotide position can be analyzed faithfully directly through PCR in a process that supersedes further tedious analysis. The effects are dependent on the combination of DNA polymerase and primer probe $4^{\prime} \mathrm{C}$-modification. Both pyrimidine derivatives $\left(T^{V_{i}}\right.$ and $\mathrm{dC}^{\mathrm{V}^{\mathrm{i}}}$ ) presented herein are able to differentiate single nucleotide variations. Thus, it can be anticipated that all transitional SNPS, which are the most common type and represent two-thirds of the total in humans, ${ }^{[11]}$ can potentially be analyzed by using the depicted set-up.

Our studies revealed considerable differences among the enzymes studied. While Vent(exo - ) DNA polymerase tolerates relatively bulky $4^{\prime} \mathrm{C}$ modifications like a $4^{\prime} \mathrm{C}$-vinyl group, the other enzymes are less tolerant in this respect. While Exo- Pfu DNA polymerase was able to use the smallest $4^{\prime} \mathrm{C}$ modification ( $T^{\mathrm{Me}}$ ) and promote significant single mismatch discriminative PCR, a further increase in bulk resulted in the loss of amplification ability. Taq DNA polymerase was unable to promote amplification even when $T^{\text {Me }}$ probes were employed. These results indicate differential constraints of the employed DNA polymerases imposed on the 3 '-terminal nucleotide. While family B DNA polymerases appear to tolerate several $4^{\prime} \mathrm{C}$ modifications Taq DNA polymerase, which is a member of the DNA polymerase family $A$, is more reluctant in this respect. However, significant differences can also be observed between the family $B$ DNA polymerase members Exo- Pfu and Vent(exo - ). Interestingly, the observed effects for Vent(exo -) DNA polymerase correlate with the bulk of the modification. With increasing bulk of the $4^{\prime} \mathrm{C}$ modification increased single nucleotide discrimination by PCR is observed (from $T^{H}$ over $T^{M e}$ and $T^{\text {Ey }}$ to $T^{V_{i}}$ ). Further extension of bulk exceeds the limits imposed by the constraints of the DNA polymerase and results in the loss of any DNA amplification ability. These features might suggest that steric constraints contribute to the selectivity of the outcome of this process. ${ }^{[44]}$ Nevertheless, additional functional and structural studies are needed to corroborate this assumption.

Further advancements along this line might be obtained through further variations of the nature and locus of the modification. Interestingly, it has been reported recently that primer probes bearing $3^{\prime}$-terminal $4^{\prime} \mathrm{C}-2^{\prime} \mathrm{O}$-methylene modifications (so called locked nucleotides or LNAs) increase single nucleotide discrimination in similar vein. ${ }^{[45]}$ The degree of differentiation is of the same order as seen with our system despite the fact that the composition of the modification and the employed DNA polymerase differ significantly. These results are the first indications that a variety of nucleotide modifications are suitable for the envisaged aim, and further studies along this line are called for.

In summary, we have shown that hydrophobic $4^{\prime} \mathrm{C}$ modifications introduced at the $3^{\prime}$ end of primer termini are able to differentiate significantly between single nucleotide mismatches in real-time PCR. The magnitudes of the effects vary with the employed $4^{\prime} \mathrm{C}$ modification and the sequence context studied. The described approach should be useful for the direct diagnosis of single nucleotide variations within genes, like single nucleotide polymorphisms or mutations, through PCR without the need for further time- and cost-intensive post-PCR analysis. In the future, we will investigate whether the depicted chemical approach to modulate DNA polymerase function can be further advanced through variations in the chemical modifications and the positions where the modifications are introduced.

\section{Experimental Section}

DNA primer probe synthesis: The syntheses of primer strands were carried out on a DNA synthesizer (Applied Biosytems, Model 392) on $0.2-\mu \mathrm{mol}$ scale by using commercially available $\beta$-2-cyanoethylphosphoamidites and either unmodified or solid supports bearing $5^{\prime} O$ dimethoxytrityl-protected $4^{\prime} \mathrm{C}$-modified nucleoside residues. The syntheses of DNA strands bearing $4^{\prime} \mathrm{C}$-modified nucleosides $\mathrm{T}^{\mathrm{Me}}, \mathrm{T}^{\mathrm{i}}$, $\mathrm{T}^{\mathrm{Et}}$, and $\mathrm{dC}^{\mathrm{Vi}}$ have been described before. ${ }^{[29,33]}$ For the synthesis of DNA strands containing $T^{\mathrm{Ey}}, \mathrm{T}^{\mathrm{Pe}}$, and $\mathrm{T}^{\mathrm{Be}}$, the nucleosides were synthesized following published procedures ${ }^{[3,46]}$ and subsequently 5'O-dimethoxytritylated.

General procedure for $5^{\prime} \mathrm{O}$-dimethoxytritylation of $4^{\prime}$-modified thymidines: The nucleosides were coevaporated twice with pyridine and dissolved in pyridine $\left(5 \mathrm{~mL} \mathrm{mmol}^{-1}\right)$, then $4,4^{\prime}$-dimethoxytrityl chloride (1.5-2.0 equiv) and a catalytic amount of 4-dimethylaminopyridine were added at $20^{\circ} \mathrm{C}$. When TLC analysis indicated complete consumption of the starting material $(12-20 \mathrm{~h})$, the reaction was quenched by addition of excess methanol and stirring was continued for $30 \mathrm{~min}$. The solvents were removed under reduced pressure and the remaining residue was subjected to column chromatography on silica gel (ethyl acetate/cyclohexane $2: 1 \rightarrow 10: 1$ containing $\left.1 \% \mathrm{Et}_{3} \mathrm{~N}\right)$ to yield the products $(62-96 \%)$ as colorless foams.

5'O-(Dimethoxytrityl) derivate of T⿱乛龰 : ${ }^{1} \mathrm{H}$ NMR $\left(400 \mathrm{MHz},\left[\mathrm{D}_{4}\right] \mathrm{MeOH}\right)$ : $\delta=1.46\left(\mathrm{~d},{ }^{4} J=1.1 \mathrm{~Hz}, 1 \mathrm{H} ; \mathrm{CH}_{3}-5\right), 1.77\left(\mathrm{~d},{ }^{4} J=1.3 \mathrm{~Hz}, 3 \mathrm{H} ; \mathrm{CH}_{3}\right), 1.78$ $\left(d^{4}{ }^{4} J=1.4 \mathrm{~Hz}, 3 \mathrm{H} ; \mathrm{CH}_{3}\right), 2.35-2.39\left(\mathrm{~m}, 2 \mathrm{H} ; \mathrm{H}-2 \mathrm{a}^{\prime}, \mathrm{H}-2 \mathrm{~b}^{\prime}\right), 3.27\left(\mathrm{~d}^{2}{ }^{2} J=\right.$ $\left.10.6 \mathrm{~Hz}, 1 \mathrm{H} ; \mathrm{H}-5 \mathrm{a}^{\prime}\right), 3.45\left(\mathrm{~d},{ }^{2} J=10.5 \mathrm{~Hz}, 1 \mathrm{H} ; \mathrm{H}-5 \mathrm{~b}^{\prime}\right), 3.84(\mathrm{~s}, 6 \mathrm{H}$; 
$\left.\mathrm{OCH}_{3}\right), 4.80\left(\mathrm{dd},{ }^{3} \mathrm{~J}=7.3 \mathrm{~Hz}, 1 \mathrm{H} ; \mathrm{H}-3^{\prime}\right), 5.43\left(\mathrm{~m}, 1 \mathrm{H} ; \mathrm{H}_{\text {viny }}\right), 6.16$ (dd, $\left.{ }^{3} J=6.4,{ }^{3} \mathrm{~J}=5.3 \mathrm{~Hz}, 1 \mathrm{H} ; \mathrm{H}-1^{\prime}\right), 6.91-6.95\left(\mathrm{~m}, 4 \mathrm{H} ; \mathrm{H}_{\text {arom }}\right), 7.27-7.42(\mathrm{~m}$, $\left.7 \mathrm{H} ; \mathrm{H}_{\text {arom }}\right), 7.50-7.53\left(\mathrm{~m}, 2 \mathrm{H} ; \mathrm{H}_{\text {arom }}\right), 7.87\left(\mathrm{~d},{ }^{4} J=1.3 \mathrm{~Hz}, 1 \mathrm{H} ; \mathrm{H}-6\right) \mathrm{ppm}$; ${ }^{13} \mathrm{C}$ NMR $\left(100.1 \mathrm{MHz},\left[\mathrm{D}_{4}\right] \mathrm{MeOH}\right): \delta=12.5,19.3,27.5,40.9,55.9,66.3$, 71.7, 84.3, 88.2, 89.4, 111.6, 114.3, 121.1, 128.1, 129.0, 129.7, 131.62, $131.63,137.2,137.3,137.8,140.1,146.3,153.7,160.47,160.48$, $168.2 \mathrm{ppm}$; IR (KBr): $\tilde{v}=701,829,1251,1693 \mathrm{~cm}^{-1}$; MS (FAB): $\mathrm{m} / \mathrm{z}$ (\%): 599 (11) $\left[M^{+}-\mathrm{H}\right]$; HRMS (ESI): $\mathrm{m} / z$ calcd for $\mathrm{C}_{35} \mathrm{H}_{38} \mathrm{~N}_{2} \mathrm{O}_{7} \mathrm{Na}[\mathrm{M}+$ $\mathrm{Na}^{+}:$621.25710; found: 621.25497 .

5'O-(Dimethoxytrityl) derivate of $\mathrm{T}^{\mathrm{Pe}}$ : ' $\mathrm{H}$ NMR $\left(300 \mathrm{MHz},\left[\mathrm{D}_{4}\right] \mathrm{MeOH}\right)$ : $\delta=1.49\left(\mathrm{~d},{ }^{4} J=1.13 \mathrm{~Hz}, 3 \mathrm{H} ; \mathrm{CH}_{3}-5\right), 1.75\left(\mathrm{~s}, 3 \mathrm{H} ; \mathrm{CH}_{3}\right), 2.42$ (ddd, ${ }^{2} J=$ $\left.13.3,{ }^{3} J=6.0,{ }^{3} J=3.7 \mathrm{~Hz}, 1 \mathrm{H} ; \mathrm{H}-2 \mathrm{a}^{\prime}\right), 2.49-2.58\left(\mathrm{~m}, 1 \mathrm{H} ; \mathrm{H}-2 \mathrm{~b}^{\prime}\right), 3.32$ $\left(\mathrm{d},{ }^{2} J=10.2 \mathrm{~Hz}, 1 \mathrm{H} ; \mathrm{H}-5 \mathrm{a}^{\prime}\right), 3.55\left(\mathrm{~d},{ }^{2} J=10.2 \mathrm{~Hz}, 1 \mathrm{H} ; \mathrm{H}-5 \mathrm{~b}^{\prime}\right), 3.82(\mathrm{~s}$, $\left.6 \mathrm{H} ; \mathrm{OCH}_{3}\right), 4.55\left(\mathrm{dd},{ }^{3} J=5.7,3^{3} \mathrm{~J}=3.8 \mathrm{~Hz}, 1 \mathrm{H} ; \mathrm{H}-3^{\prime}\right), 5.03\left(\mathrm{~m}, 1 \mathrm{H} ; \mathrm{H}_{\text {viny }}\right)$, $5.20\left(\mathrm{dd}^{2}{ }^{2} \mathrm{~J}=1.9,{ }^{4} J=0.8 \mathrm{~Hz}, 1 \mathrm{H} ; \mathrm{H}_{\text {viny }}\right), 6.41\left(\mathrm{dd},{ }^{3} J=7.4,{ }^{3} J=6.0 \mathrm{~Hz}\right.$, $\left.1 \mathrm{H} ; \mathrm{H}^{\prime} \mathbf{1}^{\prime}\right), 6.89-6.94\left(\mathrm{~m}, 4 \mathrm{H} ; \mathrm{H}_{\text {arom }}\right), 7.25-7.39\left(\mathrm{~m}, 7 \mathrm{H} ; \mathrm{H}_{\text {arom }}\right), 7.48-$ $7.51\left(\mathrm{~m}, 2 \mathrm{H} ; \mathrm{H}_{\text {arom }}\right), 7.83(\mathrm{~d}, 4 \mathrm{~J}=1.1 \mathrm{~Hz}, 1 \mathrm{H} ; \mathrm{H}-6) \mathrm{ppm} ;{ }^{13} \mathrm{CNMR}$ (75.5 MHz, [D $]$ MeOH): $\delta=12.2,21.1,41.9,55.9,56.2,68.8,74.3,86.1$, $88.5,93.7,111.5,113.3,114.4,128.3,129.1,129.6,131.56,131.59,136.9$, 137.0, 138.1, 144.9, 146.1, 152.9, 160.48, 160.49, 167.0 ppm; IR: $\tilde{v}=$ 702, 828, 903, 1251, $1698 \mathrm{~cm}^{-1}$; MS (FAB): $\mathrm{m} / \mathrm{z}$ (\%): 585 (27) [M+ $\left.-\mathrm{H}\right]$; HRMS (ESI): $\mathrm{m} / z$ calcd for $\mathrm{C}_{34} \mathrm{H}_{36} \mathrm{~N}_{2} \mathrm{O}_{7} \mathrm{Na}[M+\mathrm{Na}]^{+}: 607.24167$; found: 607.23593

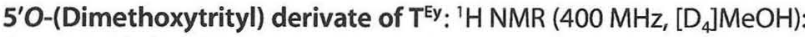
$\delta=1.50\left(\mathrm{~d},{ }^{4} \mathrm{~J}=1.1 \mathrm{~Hz}, 3 \mathrm{H} ; \mathrm{CH}_{3}-5\right), 2.46-2.61\left(\mathrm{~m}, 2 \mathrm{H} ; \mathrm{H}-2 \mathrm{a}^{\prime}, \mathrm{H}-2 \mathrm{~b}^{\prime}\right)$, $3.10\left(\mathrm{~s}, 1 \mathrm{H} ; \mathrm{H}_{\text {ethyyy }}\right), 3.48\left(\mathrm{~d},{ }^{2} J=10.2 \mathrm{~Hz}, 1 \mathrm{H} ; \mathrm{H}-5 \mathrm{a}^{\prime}\right), 3.57\left(\mathrm{~d},{ }^{2} J=\right.$ $\left.10.4 \mathrm{~Hz}, 1 \mathrm{H} ; \mathrm{H}^{-5 b^{\prime}}\right), 3.86\left(\mathrm{~s}, 6 \mathrm{H} ; \mathrm{OCH}_{3}\right), 4.80\left(\mathrm{dd},{ }^{3} J=7.5 \mathrm{~Hz}, 1 \mathrm{H} ; \mathrm{H}-3^{\prime}\right)$, $6.35\left(\mathrm{dd},{ }^{3} J=7.3,{ }^{3} \mathrm{~J}=4.7 \mathrm{~Hz}, 1 \mathrm{H} ; \mathrm{H}-1^{\prime}\right), 6.93-6.96\left(\mathrm{~m}, 4 \mathrm{H} ; \mathrm{H}_{\text {arom }}\right)$, $7.29-7.42\left(\mathrm{~m}, 7 \mathrm{H}_{;} \mathrm{H}_{\text {arom }}\right), 7.50-7.53\left(\mathrm{~m}, 2 \mathrm{H} ; \mathrm{H}_{\text {arom }}\right), 7.67\left(\mathrm{~d},{ }^{4} \mathrm{~J}=1.3 \mathrm{~Hz}\right.$, $1 \mathrm{H} ; \mathrm{H}-6)$ ppm; ${ }^{13} \mathrm{C}$ NMR $\left(100.1 \mathrm{MHz},\left[\mathrm{D}_{4}\right] \mathrm{MeOH}\right): \delta=12.3,39.9,55.9$, 67.0, 71.7, 78.7, 80.7, 85.0, 85.5, 88.4, 111.9, 114.4, 128.3, 129.1, 129.6, $131.6,136.8,136.9,137.7,146.0,152.3,160.56,160.57,166.4$ ppm; IR: $\tilde{\nu}=702,830,1252,1688,3277 \mathrm{~cm}^{-1}$; MS (FAB): $\mathrm{m} / \mathrm{z}$ (\%): 569 (32) $\left[\mathrm{M}^{+}-\mathrm{H}\right]$; HRMS (ESI): $\mathrm{m} / \mathrm{z}$ calcd for $\mathrm{C}_{33} \mathrm{H}_{32} \mathrm{~N}_{2} \mathrm{O}_{7} \mathrm{Na}[\mathrm{M}+\mathrm{Na}]^{+}$: 591.20998; found: 591.21101 .

For the synthesis of primer probes bearing $\mathrm{T}^{\mathrm{Ey}}, \mathrm{T}^{\mathrm{Pe}}$, and $\mathrm{T}^{\mathrm{Be}}$ at the $3^{\prime}$ end, the $5^{\prime} \mathrm{O}$-dimethoxytrityl ethers were coupled to a succinylated long-chain alkyl amine controlled pore glass (LCAA-CPG) support by applying standard procedures. ${ }^{[33]} \mathrm{A}$ standard method for $\beta$-cyanoethylphosphoamidites was used, with the exception that the coupling time of the first three nucleotides was extended to $10 \mathrm{~min}$ when modified supports were employed. Yields for modified oligonucleotides are comparable to those obtained for unmodified oligonucleotides. After synthesis (trityl-off), the oligonucleotides were cleaved from the support by treatment with concentrated $\mathrm{NH}_{4} \mathrm{OH}$ at $55^{\circ} \mathrm{C}$ for $12 \mathrm{~h}$. All primer DNA strands were subsequently purified by preparative electrophoresis on a $12 \%$ polyacrylamide gel containing $8 \mathrm{~m}$ urea. The integrity of all modified oligonucleotides was confirmed by MALDI-TOF MS. The unmodified DNA reverse primers were purchased from MWG, Germany, and PAGE purified as described above. For sequences, see below.

Real-time PCR experiments: Real-time PCR was performed by using ABI PRISM 7700 or iCycler (BIORAD) systems. The reactions were performed in an overall volume of $50 \mu \mathrm{L}$ containing $4 \mathrm{pM}$ of the respective templates, or $100 \mathrm{ng}$ human genomic DNA (Roche), in the respective buffers provided by the suppliers. Buffer for Taq DNA polymerase (Promega): $10 \mathrm{~mm}$ tris(hydroxymethyl)aminomethane/ $\mathrm{HCl}$ (Tris- $\mathrm{HCl} ; \mathrm{pH} 9.0$ at $25^{\circ} \mathrm{C}$ ), $50 \mathrm{~mm} \mathrm{KCl}, 1.5 \mathrm{~mm} \mathrm{MgCl}, 0.1 \%$ Triton $\mathrm{X}$-100. Buffer for Exo- Pfu DNA polymerase (Stratagene): $20 \mathrm{~mm}$ Tris$\mathrm{HCl}(\mathrm{pH} 8.8), 10 \mathrm{~mm} \mathrm{KCl}, 10 \mathrm{~mm}\left(\mathrm{NH}_{4}\right) \mathrm{SO}_{4}, 2 \mathrm{~mm} \mathrm{MgSO}_{4}, 0.1 \%$ Triton $\mathrm{X}-100,0.1 \mathrm{mg} \mathrm{mL}^{-1}$ nuclease-free bovine serum albumin. Buffer for Vent(exo -) DNA polymerase (NEB): $20 \mathrm{~mm}$ Tris-HCl (pH 8.8), $10 \mathrm{~mm}$
$\mathrm{KCl}, 10 \mathrm{mM}\left(\mathrm{NH}_{4}\right) \mathrm{SO}_{4}, 2 \mathrm{mM} \mathrm{MgSO}_{4}, 0.1 \%$ Triton X-100. The final mixtures contained deoxynucleoside triphosphates $(200 \mu \mathrm{m}$ each of dATP, dGTP, dCTP, and TTP), primers ( $0.5 \mu \mathrm{m}$ each of respective primer probe and reverse primer), SybrGreen $110000 \times$ solution in dimethylsulfoxide (1/50000 aqueous dilution; Molecular Probes), and 3 units of Taq DNA polymerase or 1.5 units of Exo- Pfu DNA polymerase or 1.2 units of Vent (exo-) DNA polymerase (units defined by the supplier). All PCR amplifications were performed by employing the following program: initial denaturation at $95^{\circ} \mathrm{C}$ for $3 \mathrm{~min}$, 40 cycles of denaturation at $95^{\circ} \mathrm{C}$ for $30 \mathrm{~s}$, primer annealing at $55^{\circ} \mathrm{C}$ for $35 \mathrm{~s}$, and extension at $72^{\circ} \mathrm{C}$ for $40 \mathrm{~s}$. The presented results are from at least three independent measurements of triplicates that originated from one master mixture.

DNA sequences: Sequences in the Farber disease context: Primer probe FarT ${ }^{R}: 5^{\prime}$-d(CGTTGGTCCTGAAGG AGG AT $\left.{ }^{R}\right)$-3'; reverse primer: 5'-d(CGCGCAGCACGC GCCGCCGT)-3'; reverse primer for human genomic DNA: 5'-d(TCTGAAACTTAATTTCTTTGC)-3'; target template $\operatorname{FarX}(\mathrm{X}=\mathrm{A}, \mathrm{G}, \mathrm{C}$, or T): 5'-d(CCGTCAGCTGTGCCGTCG CGCAGCACGCGC CGCCGT GGACAG AGG ACT GCA GAAAAT CAACCTXTCCTCCTTCAG GACCAACGTACAGAG)-3'.

Sequences in the Factor $V$ Leiden disease context: Primer probe LeiT ${ }^{R}$ : 5'-d(CAA GGACAAAATACCTGTATTCCTT ${ }^{R}$ )-3'; reverse primer: $5^{\prime}$-d(GACATCATG AGAGACATCGC)-3'; target template LeiX ( $X=A$ or G): $5^{\prime}$-d(GACATC ATGA GAGACATCG CCT CTGGGCTAATAG GACTACTTCTAATCTG TAA GAG CAG ATCCCT GGA CAG GCX AGG AATACAGGTATTTGTCCTTG)-3'.

Sequences in the BRAF context: Primer probe Braft ${ }^{R}: 5^{\prime}-d(G A C C-$ CACTCCATCGAGATTTC T ${ }^{\mathrm{R}}$ )-3'; reverse primer: 5'-d(AGAGGAAAGATGAAGTACTATG)-3'; target template BrafX ( $\mathrm{X}=\mathrm{A}$ or $\mathrm{T})$ : $5^{\prime}$ d(CAACTG TTCAAACTG ATG GGACCCACT CCATCG AGATTT CXC TGTAGCTAG ACC AAA ATC ACCTATTIT TACTGT GAG GTC TTC ATG AAGAAATATATC TGA GGT GTA GTA AGTAAA GGA AAA CAG TAG ATCTCATITTCCTATCAG AGC AAG CATTAT GAA GAG TITAGGTAAGAGATC TAATTTCTATAATTCTGTAATATA ATATTC TITAAAACATAG TAC TTC ATC TIT (CTCT)-3'.

Sequences in the DPyD context: Primer probe DpyDT $: 5^{\prime}-\mathrm{d}(G T T T T A$ GATGTTAAATCACACTTAT ${ }^{\mathrm{R}}$ )-3'; reverse primer: $5^{\prime}$-d(AAAGCTCCTTTCTGAATATTGAG)-3'; target template DPyDX ( $\mathrm{X}=\mathrm{A}$ or $\mathrm{T}$ : $5^{\prime}$-d(AAA ATG TGA GAA GGG ACCTCATAA AATATG TCATATGGA AAT GAG CAG ATA ATA AAG ATTATA GCTTIT CTTTGTCAAAAG GAG ACT CAATATCTTTACTCT TTCATCAGG ACATTG TGA CAA ATG TITCCC CCAGAATCATCC GGG GAACCACCTCTG GCCCCATGTATG GCC CTGGACAAAGCT CCTTTCTGA ATATTG AGCTCATCA GTG AGA AAA CGG CTGCATATT GGT GTC AAA GTG TCA CTG AAC TAA AGG CTG ACTTTCCAGACAACX TAA GTGTGATTTAAC ATC TAAAAC)-3'.

Oligonucleotides FarX and LeiX were synthesized and purified by IBA, Göttingen, Germany. BrafX und DPyDX were obtained through PCR amplification of the respective fragments from human genomic DNA (Roche).

DNA thermal denaturation studies: Melting curves were recorded on a Lambda 2 spectrometer (Perkin-Elmer) equipped with a PTP-6 temperature control device. Data were obtained from three individual cooling/heating cycles. Melting temperatures $\left(T_{m}\right.$ values in ${ }^{\circ} \mathrm{C}$ ) were obtained from the maximum of the first derivative of the melting curve (absorbance at $260 \mathrm{~nm}\left(A_{260}\right)$ versus temperature). Measurements were conducted in the Vent(exo -) DNA polymerase buffer $\left(10 \mathrm{~mm} \mathrm{KCl}, 10 \mathrm{~mm}\left(\mathrm{NH}_{4}\right) \mathrm{SO}_{4}, 20 \mathrm{~mm}\right.$ Tris- $\mathrm{HCl}(\mathrm{pH} 8.8), 2 \mathrm{~mm}$ $\mathrm{MgSO}_{4}$; see above) and contained $900 \mathrm{~nm}$ duplex DNA. The mixtures were heated to $95^{\circ} \mathrm{C}$ for $5 \mathrm{~min}$ and slowly cooled to room temperature prior to the melting curve measurements. A measurement of the buffer was conducted separately and subtracted from the spectra resulting from the sample. 33-mer templates: $5^{\prime}-d(A A A$ 
TCA ACC TXT CCT CCT TCA GGA CCA ACG TAC)-3' where $X=A, G, C$ or T. Primer strand FarT $T^{R}: 5^{\prime}$-d(CGT TGG TCC TGA AGG AGG AT $\left.{ }^{R}\right)-3^{\prime}$.

\section{Acknowledgements}

Financial support by the Deutsche Forschungsgemeinschaft, the Volkswagen Foundation, Roche Diagnostics, the Fonds der Chemischen Industrie, and the Dr. Otto Röhm Gedächtnisstiftung is gratefully acknowledged. We thank Marianne Engesser for recording the HRMS spectra.

Keywords: DNA polymerase - genomics • oligonucleotides • polymerase chain reaction - polymorphism

[1] L. Licinio, M. Wong, Pharmacogenomics, Wiley-VCH, Weinheim, 2002.

[2] J. J. McCarthy, R. Hilfiker, Nat. Biotechnol. 2000, 18, 505.

[3] W. E. Evans, M. V. Relling, Science 1999, 286, 487.

[4] M. V. Relling, T. Dervieux, Nat. Rev. Cancer 2001, 1, 99.

[5] M. Chicurel, Nature 2001, 412, 580.

[6] P. Y. Kwok, Annu. Rev. Genom. Hum. Genet. 2001, 2, 235.

[7] B. W. Kirk, M. Feinsod, R. Favis, R. M. Kliman, F. Barany, Nucleic Acids Res. 2002, 30, 3295.

[8] A. C. Syvanen, Nat. Rev. Genet. 2001, 2, 930.

[9] M. M. Shi, Clin. Chem. 2001, 47, 164.

[10] I. G. Gut, Hum. Mutat. 2001, 17, 475.

[11] R. M. Twyman, S. B. Primrose, Pharmacogenomics 2003, 4, 67.

[12] P. Y. Kwok, X. Chen, Curr. Issues Mol. Biol. 2003, 5, 43.

[13] V. Lyamichev, A. L. Mast, J. G. Hall, J. R. Prudent, M. W. Kaiser, T. Takova, R. W. Kwiatkowski, T. J. Sander, M. de Arruda, D. A. Arco, B. P. Neri, M. A. Brow, Nat. Biotechnol. 1999, 17, 292.

[14] S. Tyagi, F. R. Kramer, Nat. Biotechnol. 1996, 14, 303.

[15] K. J. Livak, Genet. Anal. 1999, 14, 143.

[16] C. R. Newton, A. Graham, L. E. Heptinstall, S. J. Powell, C. Summers, N. Kalsheker, J.C. Smith, A. F. Markham, Nucleic Acids Res. 1989, 17, 2503.

[17] R. A. Gibbs, P. N. Nguyen, C. T. Caskey, Nucleic Acids Res. 1989, 17, 2437.

[18] S. Germer, M. J. Holland, R. Higuchi, Genome Res. 2000, 10, 258.

[19] D. Y. Wu, L. Ugozzoli, B. K. Pal, R. B. Wallace, Proc. Natl. Acad. Sci. USA 1989, $86,2757$.

[20] L. Shively, L. Chang, J.M. LeBon, Q. Liu, A. D. Riggs, J. Singer-Sam, Biotechniques 2003, 34, 498.

[21] Z. Guo, Q. H. Liu, L. M. Smith, Nat. Biotechnol. 1997, 15, 331.

[22] Y. Ishikawa, K. Tokunaga, K. Kashiwase, T. Akaza, K. Tadokoro, T. Juji, Hum. Immunol. 1995, 42, 315
[23] J. Wilhelm, H. Reuter, B. Tews, A. Pingoud, M. Hahn, Biol. Chem. 2002, 383, 1423.

[24] D. Summerer, A. Marx, Angew. Chem. 2001, 113, 3806; Angew. Chem. Int. Ed. 2001, 40, 3693.

[25] D. Summerer, A. Marx, J. Am. Chem. Soc. 2002, 124, 910.

[26] M. Strerath, D. Summerer, A. Marx, ChemBioChem 2002, 3, 578.

[27] M. Strerath, J. Cramer, T. Restle, A. Marx, J. Am. Chem. Soc. 2002, 124, 11230.

[28] J. Cramer, M. Strerath, A. Marx, T. Restle, J. Biol. Chem. 2002, 277, 43593.

[29] M. Strerath, A. Marx, Angew. Chem. 2002, 114, 4961; Angew. Chem. Int. Ed. 2002, 41, 4766 .

[30] B. Tews, J. Wilhelm, D. Summerer, M. Strerath, A. Marx, P. Friedhoff, A. Pingoud, M. Hahn, Biol. Chem. 2003, 384, 1533.

[31] S. Meuer, C. Wittwer, K. Nakagawara, Rapid Cycle Real-Time PCR, Springer, Berlin, 2001.

[32] T. B. Morrison, J. J. Weis, C. T. Wittwer, Biotechniques 1998, 24, 954.

[33] I. Detmer, D. Summerer, A. Marx, Eur. J. Org. Chem. 2003, 1837.

[34] J. Bär, T. Linke, K. Ferlinz, U. Neumann, E. H. Schuchman, K. Sandhoff, Hum. Mutat. 2001, 17, 199.

[35] A. Kornberg, T. A. Baker, DNA Replication, 2nd ed., W. H. Freeman and Company, New York, 1991.

[36] J. Zhang, K. Li, D. Liao, J. R. Pardinas, L. Chen, X. Zhang, Lab. Invest. 2003 $83,1147$.

[37] H. Engel, L. Zwang, H. van Vliet, J. J. Michiels, J. Stibbe, J. Lindemans, Thromb. Haemostasis 1996, 75, 267.

[38] S. A. DelRio-LaFreniere, R. C. McGlennen, Mol. Diagn. 2001, 6, 201.

[39] H. Davies, G. R. Bignell, C. Cox, P. Stephens, S. Edkins, S. Clegg, J. Teague, H. Woffendin, M. J. Garnett, W. Bottomley, N. Davis, N. Dicks, R. Ewing, Y. Floyd, K. Gray, S. Hall, R. Hawes, J. Hughes, V. Kosmidou, A. Menzies, C. Mould, A. Parker, C. Stevens, S. Watt, S. Hooper, R. Wilson, H. Jayatilake, B. A. Gusterson, C. Cooper, J. Shipley, D. Hargrave, K. Pritchard-Jones, N. Maitland, G. Chenevix-Trench, G. J. Riggins, D. D. Bigner, G. Palmieri, A Cossu, A. Flanagan, A. Nicholson, J. W. C. Ho, S. Y. Leung, S. T. Yuen, B. L. Weber, H. F. Siegler, T. L. Darrow, H. Paterson, R. Marais, C. J. Marshall, R. Wooster, M. R. Stratton, P. A. Futreal, Nature 2002, 417, 949.

[40] X. X. Wei, H. L. McLeod, J. McMurrough, F. J. Gonzalez, P. FernandezSalguero, J. Clin. Invest. 1996, 98, 610.

[41] J. Sambrook, D. Russell, Molecular Cloning: A Laboatory Manual, Vol. 2, Cold Spring Harbor Laboratory Press, Cold Spring Harbor, NY, 2001.

[42] I. Detmer, D. Summerer, A. Marx, Chem. Commun. 2002, 2314.

[43] K. Ketomaki, H. Hakala, H. Lonnberg, Bioconjugate Chem. 2002, 13, 542.

[44] E. T. Kool, Annu. Rev. Biochem. 2002, 71, 191.

[45] D. Latorra, K. Campbell, A. Wolter, J. M. Hurley, Hum. Mutat. 2003, 22, 79.

[46] I. Sugimoto, S. Shuto, S. Mori, S. Shigeta, A. Matsuda, Bioorg. Med. Chem. Lett. 1999, 9, 385. 